\title{
食道の通過機構に関する筋電図学的研究 異物の影響
}

\author{
大川和春，八木正勝，佐々木均， \\ 増田信明，平山方哉*
}

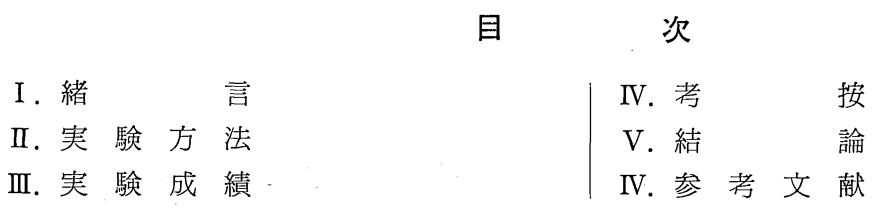

緒言

食道の通過障害および食道異物は，臨床的にしばしば遭遇する症状である。その為, 従来より諸 学者により臨床的観点から検討が進められ，また基礎的見地から，ての種の問題に関し検討が加え られ，その生理機構が解明されて来た。

咽頭と胃を結合する膜管から構成されている食道を，発生学的化考察すると，食道は特異な臟器 亿属する之考光られ，興味深い文献も少なくない，人の食道は横絞筋わよび平滑筋の両種の筋肉よ り構成されている。しかし, 胎生期に平滑筋として発達して来て筋肉群の一部が, 横絞笳に変わる と云う特異な発生過程を経由すると云われている。 また解剖学的に横絞筋に分類される筋群も, 電 気生理学的に両種の筋肉の中間的性質を保持しているととが証明される。乙の様な生理および解剖 学的特性が，食道異物の発生に関連する重要因子として注目されている.

食道筋を電気刺激すると，刺激条件によつて変化する特異な筋収縮が営なまれるのが観察され

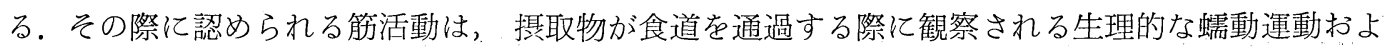
び食道異物の症例において認少られる食道壁の過興奮による病的運動の発生機構を, 解明する鍵を 握るものとして興味深い，またての種の研究は，臨床的にも意義のある課題である.

食道の通過機構としての一次性及び二次性蝡動運動に関しては，幾多の文献が発表されたが，食 道異物に対する食道筋の反射性筋活動に関しては，未だ十分とは云えない。私共は，食道異物住対 する食道笳の特異な反射性運動に焦点をしぼり, 更に食道の通過機構に関して検索した。換言すれ ば，䜩下された摂取物などの内容物に対し，食道筋が如何なる反射性筋活動を営むかを筋電図学的 に研究し, 更に食道壁に対し, 持続性の刺激源となる食道異物に対する食道筋の反射性筋活動状態 を検討することが，実験の目的である。

\section{実 験 方 法}

実験動物として，平均 $9 \mathrm{~kg}$ の成犬を用いた。 チオ ペントバルビタール $30 \mathrm{mg} / \mathrm{kg}$ の静脈脎醉を行い, 背 位に固定した．頸部正中線に皮切を行い，血管および 神経の副損傷をさけて喉頭・気管および食道壁を注意
深く剝離し，露出した．次に気管を側方に圧排し，食 道譬に分布する末梢神経および血管を損傷しない様に 永離し直径 $0.5 \mathrm{~cm}$ の食道壁を露出した．白金線双極刺 激電極を用いて，末梢神経に接触しない様に注意しな

*京都府立医科大学耳鼻咽喉科学教室（主任：中村文雄教授） 
がら，空状に露出された食道筋を直接刺激した，筋䉓 図の記録は，刺激部位の口腔側および肛門側に，縦列 に $1 \mathrm{~cm} の$ 相互間隔をもつて数本の記録電極を食道筋 に插入した。

刺激は, 持続時間 $0.1 \mathrm{msec}, 10 \mathrm{volt}$ の直角波を用い, 刺激装置は日本光電製 MSE-3R を用いた。筋活動電 位の記録は，同心型針電極を所定の筋肉に插入し，ブ ラウン管オッシロスコープに於て観察し記録した。誘

\section{実 験 成 績}

(1)食道筋を 直接刺激することで，多相性から一相 性の種々の波形を有する筋放電が記録される．との 際,一般に誘導部位と刺激部位との間の距離が遠い程, 多相性の波形から一相性の波形へと変化するのが認 められる. 筋放電の振幅に関しては, 刺激点より遠い 程小さく，持続時間は短くなる。すなわち，振幅わよ び持続時間は，距離に反比例して小さくなつた。また 潜伏時間は，刺激部位と誘導部位との間の距離に比例 して延長した．換言すれば，刺激点と誘導部位との間 の距離が長い程, 刺激により誘発された筋収縮は弱く なるが，乙の傾向は，刺激部位より口腔側において著 明である．口腔側では，刺激部位より口腔側に $1 \mathrm{~cm}$ 移動するととで，同部位からの誘発筋放電が記録され ない．てれに反し肛門側では， $4 \mathrm{~cm} の$ 部位において も誘発筋放電が記録された。

記録電極を固定し，刺激電極を上下に移動せしめて 刺激点と誘導部位との位置的関係を変化せしめ, 反複 し検討を加えたが，刺激は口腔側と伝播され難いと言 う原則は，常に認められた。

(Fig. 1，2 参照)

(2)喉頭および横隔膜の一部を含めて全摘出した新鮮 食道を, 実験方法にて記述した条件に保存し，食道筋 を直接刺激した。

单発刺激によつて, 食道筋はFig. 3 の左図の如く特 異な収縮運動を認めた。すなわち，刺激部位は著明に 彎縮状態を示し，同部位は外観上“クビレ”た様に見え る. この際注意深く観察すると, この刺激によつて誘 発されたいわゆる“クビレ”た部位の肛門側に，食道壁 が外部に向つて膨隆するのが認められる．換言すれば 食道内腔が拡張するのが認められた。乙の様な特異な 戀縮と膨隆汃ら構成される現象は，頸部食道よりも胸 部および腹部食道に於て著明に認められた。この様な 現象は食道内に直径 $1 \mathrm{~cm}$ のチュブを挿入して食道 の形態を保つと，容易に観察される. 刺激電極を食道
導した活動電位の増幅には，日本光電製の Universal Dual-Beam Oscilloscope VG-7を用い，またスピー カを結合してスパイクを音として聞く様にした。

筋電図の記録は解剖学的に，また手術操作の容易な 頸部食道筋を，主として対象とした。更に全摘出した 新鮮食道を, $37^{\circ} \mathrm{C} の$ 生理的食塩水を容れた容器に入れ て乾燥および温度の低下を防ぐ様に工夫し，食道筋を 直接電気刺激して食道筋の収縮状態を観察した。

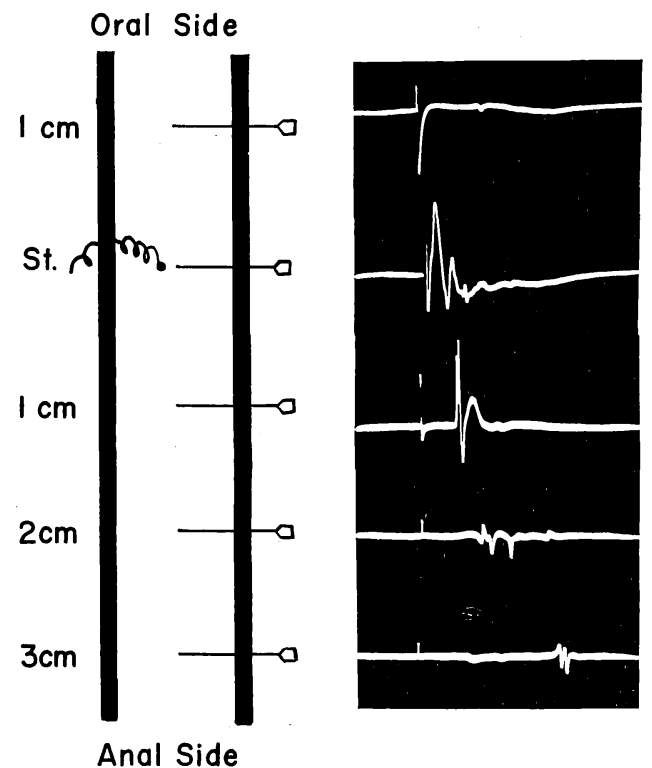

1000 cps

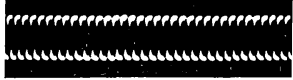

Fig. 1 ：刺激部位より胃側に移行するにつれて誘発さ れる筋放電の振幅は減少し, 持続時間の短縮 および潜時の医長が認められる。刺激の胃側 方向への伝播偏側性に注意するとと.

筋に接触させながら，頸部より腹部に移動させると蠕 動椂運動が認められる。（Fig. 3 参照）

(3)摘出された新鮮食道に対し連続刺激を加えると, 刺激部位の強縮状態及び肛門側の膨隆のみならず, 刺 激部位の口腔側においても膨隆を生じるのが認められ た。換言すれば,いわゆる“クビレ”の上下に膨隆が認め られたとの状態を食道内腔側より表現すれば，狭窄の 上下に拡張が認められたと表現出来る。しかし刺激部 


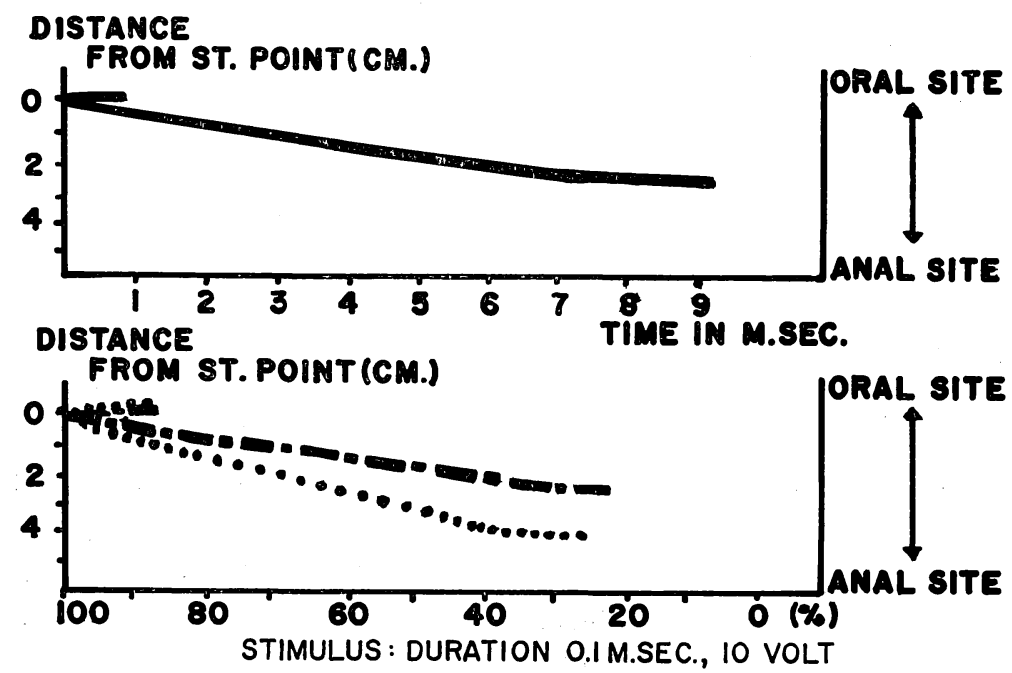

Fig. 2 : 誘発觔放電の振幅 および持続時間は 誘導部位と刺激点 の距離に反比例し て減少する。乙れ そ反して潜時は距 離に比例する。刺 激伝導速度は $2.5 \mathrm{~m}$ /sec である.

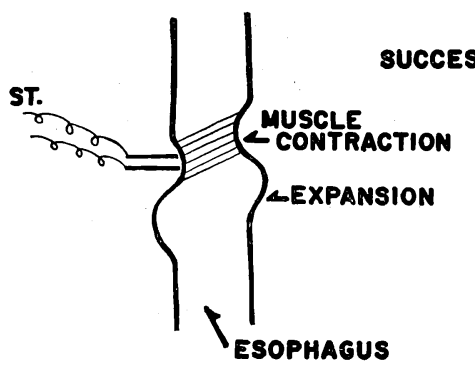

考

食道筋の解剖学的構築は, 動物の種類によつて異つ た所見が得られてい西. 食道は 2 層の筋肉群によつて 構成された膜管であつて, 仔ネコでは食道筋は前壁正 中線に起り，後下方に斜走して後壁正中線に終止する 筋線維より成る外首と, 輪走する内層との 2 層に区別 される.外層の全域および内層の上約 $1 / 3$ は横紋筋, 内 層の下 $2 / 3$ は大部分が平滑筋で占められる. マウス・ ラッテでは両首が互に交叉する方向に斜走する横紋筋 よりなり, 一部の横紋筋線維は, 胃体上部にまで達し ている. 犬では, 筋首の殆んどすべてが横紋筋から構 成されている. 人の食道は上部 $1 / 4$ は横紋筋, 下部 $1 / 4$ は滑平筋より成り, 中 $2 / 4$ は両筋肉の移行部にあた り平滑筋と横紋筋が混在している. 発生学的に, 食道 の横紋筋は胎生期に平滑筋より分化し発達した筋肉で その結果特異な所見が組織解剖学的に, また電気生理
学的に得られている ${ }^{122}$. その為, 食道の横紋筋から 得られる筋電図学的所見は骨格筋と比較する上に興味 深い対象である.

食道の筋肉は，単に食道粘膜層を外部より被覆し保 護しているのではなく, 筋肉自身が神経の調節を受け て運動を営み，食塊の通過を容易ならしめている．換 言すれば，食道筋は蠕動運動を営むととで食道の通過 機構に参加していると言える.

Volkman(1814)は, 鯂下の際に認められる咽頭筋の 収縮が, 食道筋の運動を反射性に誘発すると報告した。 これに対し Wild $\left.{ }^{4}\right)$ は, 食道の運動は咽頭に関係なく, 食道の粘膜に加えられた刺激によって誘発されると発 表した. Meltzer $\left.{ }^{3}{ }^{5}\right)$ は，食道の運動を曣下に連続して 誘発される一次性蝡動と, 嚥下に関係なく局所の反射 性運動に由来して生じる二次性蠕動とに分類した。 
Mosso( ${ }^{(6)}$ は, すべての食道の蠕動運動は, 中枢神経系の 調節を受けて営まれると発表した。.日比野》は，両側 迷走神経の切断が局所反射運動を消失せしめるととを 実験的に証明した. Hwang ${ }^{8}$ は, 胸部食道の二次性蠕 動運動に関与する求心性神経線維が, 迷走神経の運動 線維と混在しているてとを電気生理学的に証明したと している。また頸部食道関しては, ガレ一吻合技に求 心性線維が走向しているととを暗示した。換言すれば, Hwangは Mossoの学説と同様に, 蠕動運動が中枢神経 系の監視のもとに営まれていると主張したと言える.

甲田 ${ }^{9}$ は, 二次性蠕動運動の生理的意義は, 食道通 過機構の重要因子である一次性蠕動の補助的な意味と して関与し, 病的な状態, 例えば食道異物に対して積 極的に異物を胃側に移送せんとする合目的作用関与 していると発表した，食塊が何ら障害なく食道を通過 するためには，食塊が食道壁に与える刺激が，神経を 介して中枢にたえず层導されていなければならない。 換言すれば, 食道内容物が刺激源として存在し, 食道 壁と神経中枢との間に反射弓が成立されねばならない 食道の知覚には, 食道壁の拡張は必要ではなくて, 接 触刺激があれば良いと言われている(10). また食道壁の 拡張は, 縦横とも下部が最も著明に可能であつて, 中 部が最も少いとされている11).

一般に, 立位における嚥下物の食道内通過に関与す る因子は, 嚥下圧・重力および食道の蠕動運動の 3 因子 と言われている様に, 蠕動運動が通過機構に対し重要 な因子と考光られる. しかも中枢神経系の調節のもと に，臙下運動および端動運動と言う 2 種類の通過機構 がー連の連続反射性運動として営まれている. ての様 亿食道筋の運動は, 他の骨格筋と同様に, 中枢神経系の 調節が必要な条件となつている. との様に考えると， 食道筋自身は他の骨格筋に比較して, 何ら特異性を保 持していない様に考えられるが, 神経に関係なく直接 食道筋を刺激してみると, 骨格筋に見られぬ特異な反 射性活動あるいは性質を保持している．換言すれば， 同し横紋筋であつても, 食道の横紋筋は特異な性質を 保持していると言える.

食道筋を直接刺激し, 刺激の上下部位に於て筋放電 を記録すると，刺激が誘発する筋活動は胃側へ容易に 経筋肉的に伝播されるが, 口腔側へは伝播され難い。 の様な伝播方向の偏側性は, 骨格筋においては認め難 い現象である. しかも潜伏時間から計測すると, 刺激 の伝導速度は約 $2.5 \mathrm{~m} / \mathrm{sec}$ で, 骨格筋の刺激伝導速度 $4 \mathrm{~m} / \mathrm{sec}$ 亿比較すると著しく遅い。骨格筋は迅速な
運動が営なまれるのに対し, 食道筋は迅速な激しい運 動よりも， tonic な運動を必要とする機能的な面から 考擦すると, この様汇食道筋の刺激伝導速度が遅延す るのも合目的と考元られる.また，食道筋の刺激伝導 方向が偏側性を保持していることは, 食塊が常に口腔 より胃に移送されると言う機能的な面と照合すると興 味深い.

摘出した新鮮食道壁を直接刺激すると，刺激部位は 局所の筋肉の強縮のためにいわゆる“クビレ”状態を示 し，刺激により誘発された筋肉の痙縮部位より胃側 は, かえつて膨隆・拡張を認めた。膨隆部位の筋肉の 運動を注意深く観察すると，下方の食道筋壁が刺激部 位の方向へ著明に引つぱられた結果生じる様に思われ た.しかし，ての挔張が単に食道壁の筋肉の弛緩によ つて構成されていない事は, ての拡張部位の筋肉が刺 激により誘発される筋放電を記録するととで判明され る. 換言すれば，乙の拡張部位の食道筋肉群は，刺激 によつて筋収縮を誘発し,刺激部位を固定点として, 上 方に強く収縮する結果，引つぱられる様に観察される と考元られる.すなわち, 拡張部位の筋肉の運動も, 刺 激部位の筋運動之同様に, 積極的な筋活動を生し, 決し て受動的な拡張・弛緩を生ずるのではない（Fig. $1,2,3$ 参照)

刺激電極を口腔側から胃側の方向へ，食道筋壁に接 触させながら移動させると，食道の蠕動様運動が見ら れる．すなわち痙縮により生じた“クビレ”状態とその 直下の膨隆・拡張部位が，口腔側加ら胃側へ移行して 行くのが見られ，その外観は，あたかも曣下物の通過 状態の椂に観察される.

食道壁を連続刺激すると, 刺激部のいわゆる “クビ レ、状態の上部および下部に膨隆?拡張を生じる．ての 両側性の膨隆・挔張は, 刺激の加重によつて強い筋収 縮を生じ，その結果刺激が胃側のみならず口腔側にも 経筋肉的に伝播され, 上方の食道筋肉群も刺激部位の 方向へ強く収縮した結果と考えられる.

食塊がスムーズに食道を通過するためには，食塊が 刺激源として食道粘膜に接触し, その結果局所の知覚 性受容器に刺激を与えるてとが必要である．ての生理 的な刺激を，実験的に電気刺激として置き換えて考元 ると直接刺激によつて誘発された食道筋の運動および 筋電図は興味深い現象である.

刺激によつて同部位が強く痤縮状態を誘発し，その 胃側にいわゆる“クビレ”状態に接して食道壁の拡張・ 膨隆を認めることは，食道内容物例えば食謉を胃側へ 
移送させるためには，きわめて合目的である。しかも 生理的な嚥下では，曣下圧が口腔側より加わるので, 一層胃側へ輏下物を移送ないし通過するととが容易化 させられる．ての際，食道筋が斜走しているてとは， 食塊の食道腔内での回転を容易に誘起し，下方へ移
送され易くすると思われる。もし食道筋が全首共に輪 状僙走していると仮定すると, 食塊は筋収縮によつ て固定され，食道内腔に留置され易いと考光られる.

(Fig. 4)

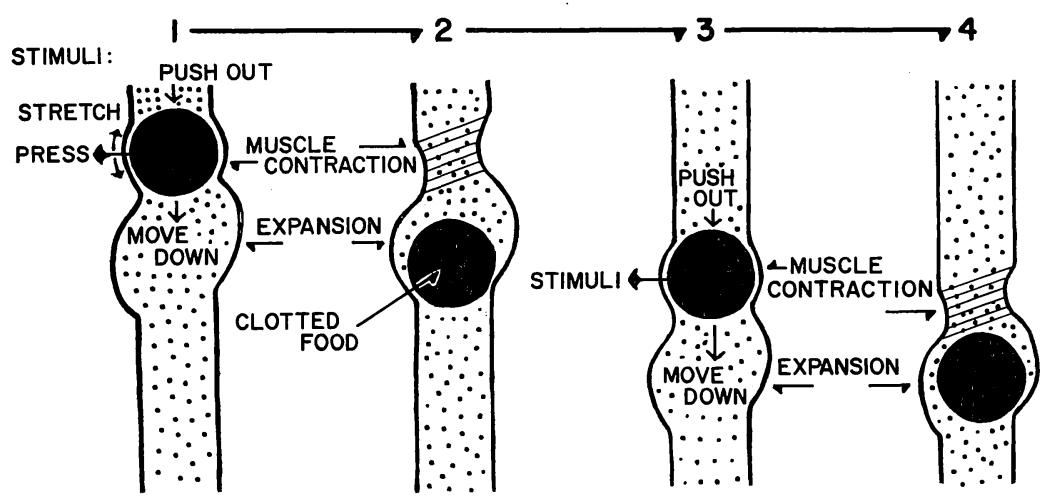

Fig. 4 : 食道の燕下物の通過機構を示した $(1 \rightarrow 4)$. 食道内容物が接触す る局所の筋肉の痙縮，および上方から加わる嚥下圧，および下部の 食道内腔の挔張および食道笳の斜走しているととなどが，内容物を 容易に下方に移送せしめる因子となる。

食道異物は臨床的にしばしば遭遇する疾患である。 食道異物は食道腔内に留置されている間, 食道粘膜に 対し刺激をたえず加えていると考えられる．ての状態 を実験的に仮定すると，連続刺激の実験に相当すると 思われる. 連続刺激が食道筋に与光られ, 刺激が加重 する結果筋収縮は著明となり，刺激部位のいわゆる ,クビレ”状態の上部および下部に膨隆, 拡張を諗起す る. この上部に生じた拡張を実際の食道異物症例にあ てはめてみると, 胃側への異物の移送効果を減弱せし めていると考えられる.

一般に食道異物は生理的狭窄部に多く認められる。 食道の生理的狭窄部位は第 1 㹟窄部位は輪状軟骨直下 第 2 㹨窄部位は気管分岐部, 第 3 狭窄部位は横隔膜貫

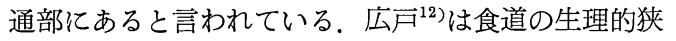
窄部位の成立は, 単に周囲藏器の圧迫によつて生じる と言う解剖学的関係の他に, 食道筋自体の機能的関係 が関与していると主張し, 胸骨上窩より左主気管支分 岐部附近までを広く第 2 狭窄部とすべきであると発表 した.すすなち胸骨上部より左主気管支分岐部に至る 間に存在する食道は横紋, 平滑筋の移行部に相当し, 嬩下圧と食道自体の運動, すなわち螨動運動の 2 種類 の通過機構の移行部に相当し, この様な生理的な原因
を重視した。

異物の発生に関与する因子としては, 以上の様な解 剖学的因子および生理学的因子が考えられて来たが, 一定の食道内部に留置された異物は, 食道粘膜に対し て刺激源となればなる程, 同部位に固定される様に, 非 合目的に局所の食道壁が痙縮運動を生じ, かえつて胃 側への移動を弱めると思われる．異物としての刺激が 連続的に食道壁に加えるととで, 蠕動か強化され, 胃 側方向への移送効果を強化するとは考学られない。し かし何らかの原因で, 例光ば嶼下圧などの内圧の変化 で少しでも留置された食道内容物が移動すると,たち まち生理的な合目的な筋収縮が連発して，肉眼的には 蠕動運動として認められると考光られる.臨床的にも， この種の現象を同意せしめる症例が少くない，例えば 内視鏡を挿入することで，食道異物は内視鏡が異物の 留置部位に達する以前に, 急に異物が胃側へ移動する 場合が少くない。

食道の生理的な蠕動運動は, 中枢神経系の調節を受 けて一連の連発運動として誘起される.蠕動運動は他 の骨格筋と同様に, 錐体路, 錐体外路および自律神経系 の支配を受け, 最終共通路は迷走神経である。もちろん Auerbach 神経叢も何らかの関与を営んでいると思わ 
れる, 食道筋にも多数の筋紡錘があつて, 自己調節機能 を営んでいると考え，筋紡錘を含む $\gamma$ 系反射が，生理 的蠕動運動には重要な反射と考えられるが, 生理的状 態でない病的な状態, 例えば食道異物などによる異常 な拡張は過興奮状態による異常な反射性筋活動を $\gamma$ 系 反射径路が誘発し，その結果かえつて食道異物が一定 部位に固定ないし留置されると考えられる.換言すれ ば,一連の $r$ 系反射により生じる運動が, 部位を異にせ
ず食道の同一部位で連続して生じる結果, 逆に異物の 胃側への移送効果を減弱するものと考えられる. 生理 的蠕動運動が, 神経を介して誘発される結果, 食道筋 への直接刺激の実験は生理的な状態と全くちがつた状 態であるが，直接刺激によつて得られた実験成績は， 生理的蠕動運動の機構を解明する鍵を握つているもの と思われ，解明の方法として合理的な方法と考えられ る.

\section{結}

\section{論}

食道の通過機構および食道異物が与える影響を筋電図学的に解明する目的で実験を行なつた。

1. 食道筋の直接刺激によつて誘発される筋放電は, 刺激部位より胃側において容易に記録され る。換言すれば，胃側の方向へ刺激伝導偏側性が認められる，強い刺激は口腔側へも刺激を伝播せ しめるが，胃側への伝播効率と比較すると弱い，伝導速度は約 $2.5 \mathrm{~m} / \mathrm{sec}$ である.

2. 直接刺激によつて, 刺激部位に痤縮を誘発し, 外観上痤縮状態はいわゆる食道壁の “クビレ” 状態として観察される. 刺激部位の胃側に゙クビレ゙部位に接して, 食道壁の膨隆, 拡張を生じる.

3. 直接刺激を連続して与えると，刺激部位のいわゆる゙クビレ゙状態を示す部位の胃側および口 腔側に食道壁の膨隆, 拡張が認められる。

4. 刺激によつて生じるいわゆる゙クビレ゙と拡張は食塊の胃側方向への移送効果をたかめる。 れに対し口腔側に生じる拡張は，逆に移送効果を減弱せしめる。

5. 食道異物は連続した刺激を食道壁に加える結果, 連続刺激時の実験と同様に, 刺激部位のい わゆる゙クビレ゙状態と同時に, 口腔側および胃側に“クビレ゙部位に接続して 食道壁の拡張を生じ る. その結果移送効果を滅弱し，食道異物は一定の部位に留置・固定されると考えられる.

稿を終るに臨み，御指導および御校閲を睗つた中村文雄教授に，樑甚なる謝意を表す。

\section{参考文献}

1）和気健二郎・鈴木清：食道神経末梢の組織学的研 究，“食道の通過障害に関する研究”文部省班研 究発表 $5: 1964$

2）河野康雄・八木正勝 : 頸部食道の筋電図, 耳鼻臨 床 $57: 3 ; 193,1964$

3) Meltzer, S.J. : Vagus Reflexes upon Oesophagus and Cardia. Brit. Med. J. 2 : 1806, 1906.

4) Wild, F. : Ueber die Peristaltische Bewegung des Oesophagus. Z. Rationel. Med. 5 : 76, 187 6.

5) Meltzer, S.J. : On the Gauses of Orderly Progress Peristaltic Movement in Esophagus. Amer. J. Physiol. 11 : 266, 1899.

6) Mosso, A. : Ueber die Bewegung der Speiseröhle, Untersuch. Z. Nature $11: 327,1876$.
7）日比野典男・川出 櫓：食道の運動に関する研究， 第 3 報 食道に於ける局所反射運動, 気食会報 $5: 4,1,1954$

8) Kao,, Hwang : Mechanism of Transportation of the Content of the Esophagus. J. Appl. Physiol. 6 : 7811954.

9）甲田博和：食道における局所蠕動の生理的意義, 気食会報 $8: 2 ； 12,1957$

10）広戸幾一郎, 他 : 食道知覚の不規則性, 気食会報 $5: 3 ; 17,1954$

11）原芳雄: 食道壁の強鞓性に関する研究,気食会報, $5: 3 ; 10,1954$

12）広戸幾一郎, 他: 食道第 2 狭窄部について, 気食 会報 $5: 3 ； 8 ， 1954$ 


\section{Current Medical Literature}

\section{Glinical Otology}

Alford, B.R.: Electrodiagnostic Studies in Facial Paralysis. Arch. Otolaryng. 85: 3 259, Mar. 1967.

Archard, J.C.: The Place of Myringotomy in the Management of Secretory Otitis Media in Children. J. Laryng. (Lond.) 81: 3; 309, Mar. 1967.

Basek, Milos: Fibrous Dysplasia of the Middle Ear. Arch. Otolaryng. 85: 1; 4, Jan. 1967.

Carr, Ch. D., et al.: Middle Ear Effusions. Acta oto-laryng. (Stockh.) 63: 1; 1, Jan. 1967.

Fuller, A.M., et al.: Chemodectomas of the Glomus Jugulare Tumors. Laryngoscope 77: 2; 218, Feb. 1967.

Hansen, J.E.: Pseudocysts of the Auricle in Caucasians. Arch. Otolaryng. 85: 1; 13, Jan. 1967.

Martins, H., et al.: Multiple Neurofibromatosis Involving the VIIIth Nerve. J. Laryng. (Lod.) 81: 3; 353, Mar. 1957,.

Maurer, H.: Biochemical Aspects of Otosclerosis. Arch. Otolaryng. 85: 3; 238, Mar. 1957.

Mawson, S.R.: Myringotomy, $\alpha$-Chymotrypsin and Reverse Politzerization for "Glue" Ears. J. Laryng. (Lond.) 81: 2; 147, Feb. 1967.

Palva, A. and Suurkari, S.: Membranous Total Closure of the External Auditory Canal. J. Laryng. (Lond.) 81: 3; 363, Mar. 1967.

Paparella, M.M., et al.: Pathogenesis and Pathology of the "Idiopathic" Blue Ear Drum. Arch. Otolalyng. 85: 3; 249, Mar. 1967.

Sammut, J.J.: The Middile Ear in Accidental Deaths. J. Laryng. (Lond.) 81: 2; 137, Eed. 1967.

Samy, L.L., et al.: Transzygomatic Approach to the Petrous Apex with a Record of Three Cases. J. Laryng. (Lond.) 81: 3; 277, Mar. 1967.

Schürmann, K., et al.: Verletzung der Arteria carotis interna an der Schädelbasis bei frontobasalen Schädelhirntraumen. Z. Laryng. Rhinol. 46: 1; 41, Jan. 1967.

Silverstein, H., et al.: Teratoma of the Middle Ear and Mastoid Process. Arch. Otoraryng. 85: 3; 243, Mar. 1967.

Slatin, H.P.: Versorgung eines Mittelohrangioms durch die Arteria carotis externa. Mschr. Ohr. hk., Wien 101: 1; 1. 1967

Wengraf, C.: A Case of Objective 'Tinnitus. J. Laryng. (Lond.) 81: 2; 143, Feb. 1967.

\section{Audiology}

Beagley, H.A., et al.: The Auditory Evoked Ccrti- cal Response as an Index of Hearing in Practical Audiometry. J. Laryng. (Lond.) 81: 3; 347, Mar. 1967.

Beal, D.D., et al.: Inner Ear Pathology of longenital Deafness. Arch. Otolaryng. (Chicago) 85: 2; 134, Fed. 1967.

Carhart, R.: Probable Mechanisms Underlying Kernicteric Hering Loss. Acta Oto-latyng. (Stockh) Suppl. 221 : 1967.

Critchley, Edmuad: The Social Development of Deaf Children. J. Laryng. (Lond.) 81: 3; 291, Mar. 1967.

Downs, M.P., et al.: A Guide to Newborn and Infant Hearing Screening Programs. Arch. Otolaryng. 85: 1; 15, Jan. 1967.

Elliott, L.L.: Descriptive Analysis of Audiometric and Psychometric Scores of Students at a School for the Deaf. J. Speech Hearing Res .10: 1; 21, Mar. 1967.

Finck, A., et al.: Auditory Sensitivity of the Mongolian Gerbil. J. Aud. Res. 6: 3; 313, July 1966.

Fricke J.E. : Auditory Fatigue and Mental Activity. J. Aud. Res. 6: 3; 283, July 1966.

Goodhill V.: Detection of Hearing Loss in Neonates. Arch. Otolaryng. 85: 1; 1, Jan. 1967.

Grove T.G.: Performance of Naive and PolePlaying Pseudomalingerers on an Unconditioned EDR Audiometric Test. J. Aud. Res. 6: 3; 337, July 1966.

Harbert, F., et al.: Audiologic Findings in Presbycusis. J Aud. Res. 6: 3; 297, July 1966.

Hochberg, I: Median Plane Lxalization of Speech. J. Aud. Res. 6: 3; 277, July 1966.

Hodgson, W.R.: Audiological Report of a Patient with Left Hemispherectomy. J. Speech Hearing Dis. 32: 1; 39, Feb. 1957.

Holmgren, L.: Hörgeräteverordnung und-anpassung in Schweden. Z. Laryng. Rhinol. 46: 1; 57, Jan. 1967.

Ilberg, C.v., et al.: Ein methodischer Beitrag zur Permeabilitätsmessung an der ReißnerMembran. Archiv Klin. exper. Ohren, Nasenund Kehlkopfheilk. 187: 3; 800, 1966.

Iinuma, T.: Evaluation of Adenosine Triphophatase Activity in the Stria Vascularis and Spiral Ligament of Normal Guinea Pigs. Laryngoscope 77: 2; 141, Feb. 1967.

Iinuma, T. et al.: Possible Effects of Various Ototoxic Drugs upon the ATP-Hydrolyzing System in the Stria Vascularis and Spiral Lig- 
ament of the Guinea Pig. Laryngoscope 77: 2; 159, Feb. 1967.

Jelert Hans: Severe Reduction of Hearing and Vestibular Involvement Caused by Vionactan. J. Laryng. (Lond.) 81: 3; 317, March 1967. Jordan, O., et al.: Treatment with Binaural Hearing Aids. Arch. Otolaryng. 85: 3; 319, Mar. 1967.

Lamb, Lloyd E., et al.: Middle Ear Reflex Measurements in Pseudohypacusis. J. Speech Hearing Dis. 32: 1; 46, Eed. 1967.

Lewes, A.N.: A Simplified Instrument for PureTone Delayed Auditory Feedback. J. Speech Hearing Res. 10: 1; 93, Mar. 1967.

Massopust, L.C., et al.: Deficits in Auditory Frequency Discrimination Following Temporal and Frontal Lobe Lesions in Monkeys. J. Aud Res. 6: 3; 261, July 1966.

De Morua, L.F.P.: Inner Ear Pathology in Acoustic Neurinoma. Arch. Othlaryng. (Chicago) 85: 2; 125, Feb. 1967.

Mehmke, S.: Die diagnostische Bedeutung der relativen Impedanzmessungen des Mittelohres Z. Laryng. Rhinol. 46: 1; 23, Jan. 1967.

Melnick, W.: Comfort Level and Loudness Matching for Continuous and Interrupted Signals. J. Speech Hearing Res. 10: 1; 99, Mar. 1967.

Muma, J.R., et al.: Békésy Excursion Size for Normal-Hearing Young Adults. J. Aud Res. 6: 3; 289, July. 1966.

Nakano, Y., et al.: NADH-Oxidizing Activity of the Labyrinthine Fluids. Arch. Otolaryng. (Chicago) 85: 1; 8, Jan .1967.

Olsen, W.O.: Artificial Mastoid Calibration of Bone Vibrators. Arch. Otolaryng. (Chicago) 85: 3; 314, Mar. 1967.

Perlman, H.B.: Progress Report: Sensorineural Deafness. Arch. Otolatyng. (Chicago) 85: 1; 110, Jan. 1967.

Proctor, C.A., et al.: Understading Hereditary Nerve Deafness. Arch. Otolaryng. (Chicago) 85: 1; 23, Jan. 1967.

Ruben, R.J.: Development of the Inner Ear of the Mouse: A Radioautographic Study of Terminal Mitoses. Acta oto-laryng. (Stockh.) Suppl. 220, 1967.

Suhenkel, K.D.: Accumulation Theory of BinauralMasked Thresholds. J. Acoust. Soc. Am. 41: 1; 20, Jan. 1967.

Schätzle, W., et al.: Histochemischer Nachweis von Proteinbausteinen in den Strukturen des Innenohres. Archiv klin. exper. Ohren-, Nasenund Kehlkopfheilk. 187: 3; 822, 1966

Schöler, W.: Zur audiologischen Einrichtung in der Fachpraxis und Fachabteilung. Mschr.
Ohr. hk., Wien 101: 1; 6, 1967

Shapiro, I., et al.: Audiologic Evaluation of Acoustic Neurinomas. J. Speech Hearing Dis. 32: 1; 29, Feb. 1967

Simmons, F.B.: Permanent Intracochlear Electrodes in Cats, Tissue Tolerance and Cochlear Microphonics. Laryngoscope 77: 2; 171, Feb. 1967.

Simmons, F.B., et al.: Endolymphatic Duct Pressure Produces Cohlear Damage. Arch. Otoaryng. (Chicago) 85: 2; 143, Feb. 1967

Studebaker. G.A.: Intertest Variability and the Air-Bone Gap. J. Speech Hearing Dis. 32: 1; 82, Fed 1967.

Wasson. H.W., et al.: Effects of Dextro-Amphetamine on Auditory. J. Aud. Res. 6: 3; 351, July 1966.

Weiss, B.A.: Auditory Sensitivity in the Goldfish. J. Aud. Res. 6: 3; 321, July 1966.

\section{Oto-microsurgery}

Bellucci, R.J.: Subluxation and Depression of Stapes Footplate. Arch. Otolaryng. (Chicabo) 85: 2; 182, Feb. 1967.

Cody, D.T.R.: Stapedectomy for Otosclerosis, Arch. Ohtolaryng. (Chicaho) 85: 2; 184, Feb. 1967.

Gundersen, T.: Congenital Molformations of the Stapes Footplate. Arch. Otolaryng. (Chicago) 85: 2; 171, Feb. 1967.

Hlaváček, V.: Long-term Results of Adipose Tissue in Stapedioplasty in Otosclerosis. J. Laryg. (Lond.) 81: 2; 209, Feb. 1967.

Kerth, J.D. : Progress Report: Otosclerosis. Arch. Otolaryng. (Chicahgo) 85: 2; 226, Feb. 1967.

Mitchell, J.F.O.: Myringoplasty by Homogenous Vein Graft. J. Laryng. (Lond.) 81: 3; 339, March 1967.

Nowinski, J.: Narrow Field Mastoidectomy in Tympanoplasty. J. Laryng. (Lond.) 81: 3; 325, Mar. 1967.

Patterson, M.E., et al.: Temporalis Fascia in Tympanic Membrane Grafting. Arch. Otolaryng. (Chicago) 85: 3; 287, Mar. 1967.

Powers, W.H., et al.: The Fixed Malleus Head. Arch. Otolaryng. (Chicago) 85: 2; 177, Feb. 1967.

Rossberg, G.: Zur operativen Versorgung der Mißbildungen des Gehörganges und des Mittelohers. Z. Laryng. Rhinol. 46: 1; 36, Jan. 1967.

Scheer, A.A.: Correction of Congenital Middle Ear Deformities. Arch. Otolaryng. 85: 3; 269, Mar. 1967.

4. Vestibular Problems

Bergan, J.J., et al.: Vascular Implications of Vertigo. Arch. Otolaryng. 85: 3; 292, Mar. 
1967.

Brandt, U., et al.: Postural Perceptions and Eye Displacements During the Variation of a Force Field Acting in the Mid-Frontal Plane. Acta oto-laryng. (Stockh.)63: 1; 49, Jan. 1967.

Graybiel, A., et al.: Streptomycin in Ménière as Disease. Arch. Otolaryng. (Chicago) 85: 2; 156, Feb. 1967.

Greiner, G.F., et al.: Ergebnisse der Nystagmographie bei Pendelstimulation. Mschr. Ohr. hk., Wien 101: 1; 13, 1967.

Hallén, O., et al.: Effect of Localized Cerebellar Lesions on the Succinoxidase Activity of Deiters' Giant Cells in Rabbits Subjected to Unilateral Vestibular Neurotomy Acta oto-laryng. (Stockh.) 63: 1; 87, Jan. 1967.

Hinchcliffe, R.: Validity of Measures of Caloric Test Response. Acta oto-laryng. (Stockh.) 63: 1; 69, Jan. 1967.

Hinchcliffe, R.: Normal Values for Caloric Tests Using Electro-oculography. J. Laryng. (Lond.) 81: 2; 221, Feb. 1967.

Hinchcliffe, R.: A Comparison of Measurements from the Clinical Caloric Test with those from the Test Using Electro-oculographic Recordings. J. Laryng. (Lond.) 81 : 2; 215, Feb. 1967.

Mehra, Y.N., et al.: Evaluation of Ewald's Second Law. An Electronystagmographic Study. Acta oto-laryng. (Stockh.) 63: 2; 33, Jan. 1967.

Milojevic, B., et al.: Secondary Phase Nystagmus: The Caloric Test. Laryngoscope 77: 2; 187, Feb. 1967.

Milojevic, B., et al.: Electronytsagmographical Study of Latent Ocular Nystagmus. Arch. Otolaryng. (Chicago) 85: 3; 283, Mar. 1967.

Norris, C., et al.: Notes on Nystagmography. Arch. Otolaryng. (Chicago) 85: 3; 265, Mar. 1967.

Peitersen, E.: Vestibulospinal Reflexes. Arch. Otolaryng. (Chicago) 85: 2; 192, Feb. 1967.

Wlodyka, J.: Neruonitis Vestibularis. Arch. Otolaryng. (Chicago) 85: 3; 298, Mar. 1976.

Yules, R.B., et al. : Effect of Drugs on After-Nystagmus Induced by Lateral Vestibular Nucleus Stimulation. Acrh. Otolaryng. (Chicago) 85: 3; 278, Mar. 1967.

Zalin. A.: On the Function of the Kinocilia and Stereocilia with Special Reference to the Phenomenon of Directional Preponderance. J. Laryng. (Lond.) 81: 2; 119, Feb. 1967.

5. Rhinology

Hagan, P.J.: Posttraumatic Anosmia. Arch. Otolaryng. (Chicago) 85: 1; 85, Jan. 1967.

Jazbi, B.: An Unusual Case of Adenocarcinoma of the Nose. Acta oto-laryng. (Stockh.) 63:
1; 65, Jan. 1967.

Sanford, D.M., et al.: Acute Leukemia Presenting as Nasal Obstruction. Arch. Otolatryng. (Chicago) 85: 1; 102, Jan. 1967.

McNeill, R.A.: Surgical Obliteration of the Maxillary Sinus. A Clinical and Experimental Study. Laryngoscope 77: 2; 202, Feb. 1967.

Puskás, F., et al.: Histochemische Untersuchungen on Nasenpolypen. Arch. klin. exper. OhrenNasen- und Kehlkopfheilk. 187: 3; 816, 1966.

Sakai, S., et al.: Proposal for the Glassification of Carcinoma of the Paranasal Sinuses. Acta oto-laryng. (Stockhl) 63: 1; 42, Jan. 1967.

Sinha, A.: Arteriography in Management of Epistaxis. J. Laryng. (Lond.) 81: 2; 235, Feb. 1967.

Ristow, W.: Transorale Neuro-und Arteriotomie zur Behandlung der Masseter-Hypertrophie. Z. Laryng. Rhino. 46: 1; 30, Jan. 1967.

Sharp, G.E.: The Hot Tongue Syndrome. Arch. Otolaryng. (Chicago) 85: 1; 90, Jan. 1967.

Walsh-Waring, G.P.: Naso-alveolar Cysts: Aetiology, Presentation and Treatment: Six Cases are Reported. J. Laryng. (Lond.) 81: 3; 263, Mar. 1967.

Winborn, C.E. : Rhinoscleroma. Arch. Otolaryng. (Chicahgo) 85: 2; 223, Feb. 1967.

Worgan, D.: Metastatic Maxillary Antrum Seminoma. J. Laryng. (Lond.) 81: 2; 241, Feb. 1967.

\section{Pharyngo-stomatology}

Ali, D.S.: Congenital Unilateral Choanal Atresia Associated with a Rhinolith. J. Laryng. (Lond.) 81: 3; 359, Mar. 1967.

Arulpragasam, A.C.: On the Treatment of Parotid Fistulae. J. Laryng. (Lond.) 81: 3; 329, Mar. 1967.

Bockmuhl, F., et al.: Die Behandlungsergebnisse der Tonsillenneoplasmen in der Deutschen Demokratischen Republik von 1954-1958, Z. Laryng. Rhinol. 46: 1; 12, Jan. 1967.

Cataldo, E., et al.: Osteoma of the Tongue. Arch. Otolaryng. (Chicago) 85: 2; 202, Feb. 1967.

Fuller, A.M., et al.: Tonsillectomy and Hemoglobin C-C Disease. Arch. Otolaryng. (Chicago) 85: 1; 99, Jan. 1967.

Ghossein, N.A., et al.: Hodgkin's Disease of the Nasopharynx. Report of a Case. Laryngoscope 77: 2; 247, Feb. 1967.

Lederman, M.: Cancer of the Pharynx: A Study Based on 2,417 Cases with Special Reference to Radiation Treatment. J. Laryng. (Lond.) 81: 2; 151, Fed. 1967.

Martinson, F.D.: Primary Tuberculosis of the Nasopharynx in a Nigerian. 81: 2; 229, Feb. 1967. McGuire, N.G.: A Method of Guillotine Tonsil- 
lectomy with an Historical Review. J. Laryng (Lond.) 81: 2; 187, Feb. 1967.

Muir, C.S., et al.: Nasopharyngeal Cancer in Sarawak (Borneo) J. Laryng. (Lond.) 81: 2; 197, Feb. 1967

Müsebeck, K., et al.: Über serotoninhaltige Zellen in den Tonsillen des Menschen. Archiv klin. exper. Ohren-, Nasen-und Kehlkopheilk. 187: 3; 773, 1966,.

Popli, S.P., et al.: Fibrosarcoma of Tonsil. J. Laryng. (Lond.) 81: 2; 245, Feb. 1967.

Puskás, F., et al.: Histochemische Untersuchung der Mukopolysaccharide in hypertrophischen und chronisch entzündeten Tonsillen. Mschr. Ohr. hk., Wien 101: 1; 24, 1967.

\section{Laryngology}

Brookler, K.H., et al.: Side-Rail Clamp for Killian-Lynch Suspension Laryngoscope. Arch. Otolaryng. (Chicago) 85: 1; 106, Jan. 1967.

Fine, J.: Microlaryngoscopy with a New Laryngoscope. Arch. Otolaryng. (Chicago) 85: 2; 216, Feb. 1967.

Frable, W.J., et al.: Cytology. Arch. Otolaryng. (Chicago) 85: 1; 50, Jan. 1967.

Holl-Allen, R.T.J., et al.: Laryngeal Nerve Paralysis and Benign Thyroid Disease. Arch. Otolatryng. 85: 3; 335, Mar. 1967.

Kuhn, A.J.: A Method of Examination of the Larynx through a Suspension Laryngoscope, Using a Bronchoscopic Telescope. Larygoscope 77: 2; 252, Feb. 1967.

Rossberg, G., et al.: Diagnose und Behandlung der Laryngozele. Z. Laryng. Rhinol. 46: 1; 49, Jan. 1967.

Shanks, J.C.: Advantages in the Use of Esophageal Speech by a Layngectomee. Laryngoscope 77: 2; 239, Feb. 1967.

Siegert, C., et al.: Funktionelle Ergebnisse nach Radiumspickung von Stimmbandkrebsen. $\mathrm{Z}$. Laryng. Rhinol. 46: 1; 4, Jan. 1967.

Striker, T.W., et al.: Prolonged Nasotracheal Intubation in Infants and Children. Arch. Otolatryng. (Chicago) 85: 2; 210, Feb. 1967.

Szpunar, J.: Laryngeal Papillomatosis. Acta oto-laryng. (Stockh.) 63: 1; 74, Jan. 1967.

\section{Phoniatrics.}

Bricker, W.A.: Errors in the Echoic Behavior of Preschool Children. J. Speech Hearing Res. 10: 1; 67, Mar. 1967.

Burkland, M. : Use of Television to Study Articulatory Problems. J. Speech Hearing Dis. 32: 1; 80, Feb. 1967.

Cooper, M., et al.: Vocal Rehabilitation for Contact Ulcer of the Larynx. Arch. Otolaryng. 85: 1; 41, Jan. 1967.
Dedo, H.H., et al.: Husson's Theory. Arch. Otolaryng. 85: 3; 303, Mar. 1957.

Ebbin, J.B., et al.: Speech Sound Discrimination of Aphasics when Intersound Interval is Varied.

J. Speech Hearing Res. 10: 1; 120, Mar. 1967.

Hanson, M.L. : Some Suggestions for More Effective Therapy for Tongue Thrust. J. Speech Hearing Dis. 32: 1; 75, Feb. 1967.

Hirsch, K.d.: Differential Diagnosis bətween Aphasic and Schizophrenic Language in Children. J. Speech Hearing Dis. 32: 1; 3, Feb. 1967.

Holland, A.L. : Some Applications of Behavioral Principles to Clinical Speech Problems. J. Speech Hearing Dis. 32: 1; 11, Feb. 1957.

Landes, B.A.: Hyporhinolalia Associated with Eustachian Tube Dysfunction. Laryngoscope 77: 2; 244, Feb. 1967

Minnigerode, B.: Das Defigurationsphänomen in der Bewegungswahrnehmung und seine Auswirkung auf das stroboskopische Kehlkopfbild. Mschr. Ohe hk., Wien 101: 1; 33, 1967.

Minnigerode, B.: Bau und Funktion des Sinus Morgagni für die menschliche Stimmbildung in neuer Sicht. Archiv. klin. exper. Ohren-, Nasen-und Kehlkopfheilk. 187: 3; 845, 1966.

Moll, K.L., et al. : Preliminary Investigation of a New Concept of Velar Activity during Speech. Cleft Palate J. 4: 58, Jan. 1967

Paulsen, K.: Der Primäre Stimmklang des menschlichen Kehlkopfes. Archiv klin. exper. Ohren-, Nasen- und Kehlkopeilhk. 187: 3; 807, 1966.

Shriner, T.H., et al.: An Equation for Assessing Language Development. J. Speech Hearing. Res. 10: 1; 41, Mar. 1967.

Warren, D.W., et al.: Oral Port Constriction, Nasal Resistance, and Respiratory Aspects of Cleft Palate Speech: An Analog Study. Cleft Palate J. 4: 38, Jan. 1966.

Webb, R., et al.: Effects of Verbal Decision Behavior upon Respiration during Speech Production. J. Speech Hearing Res. 10: 1; 49, Mar. 1967.

Weiner, P.S.: Auditory Discrimination and Articulation. J. Speech Hearing Dis. 32: 1; 19, Feb. 1967.

Wolski, W.: Hypernasality as the Presenting Symptom of Myasthenia Gravis. J. Speech Hearing Dis. 32: 1; 36, Feb. 1967.

Demark, D.R., et al.: Misarticulations of Cleft Palate Children Achieving Velopharyngeal Closure and Children with Functional Speech 
Problems. Cleft Palate J. 4: 31, Jan. 1967.

\section{Plastic Surgery}

Aduss, H., et al.: The Cavty in Complete Unilateral Cleft Lip and Palate. Arch. Otolatyng. 85: 2; 53, Jan. 1967.

Atherton, J.D.: Morphology of Facial Bones in Skulls with Unoperated Unilateral Cleft Palate. Cleft Palate J. 4: 18, Jan. 1967.

Beekhuis, G.J., et al.: Midfacial Cysts. Arch. Otolaryng. 85: 1; 62, Jan. 1967.

Bernstein, L.: Treatment of Velopharyngeal Incompetence. Arch. Otolaryng. 85: 1; 67, Jan. 1967.

Hochberg, I., et al.: Oral Stereognosis in Normal and Cleft Palate Individuals. Cleft Palate J. 4: 47, Jan. 1967.

Kremenak, C.R., et al.: Growth of Maxillae in Dogs after Palatal Surgery: I. Cleft Palate J. 4: 6, Jan. 1967.

Marquit, B.: Radiated Homogenous Cartilage in Rhinoplasty. Arch. Otolaryng. 85: 1; 78, Jan. 1967.

McNeill, K.A.: Experiences with Island Flap in Palate Surgrey. Arch. Otolaryng. 85: 1; 7.5, Jan. 1967.

Georgiade, N.G.: Anterior Palatal-Alveolar Closure by Means of Interpolated Flaps. Plast. Reconstr. Surg. 39: 2; 162, Feb. 1967.

Trauner, R., et al.: Results of Cleft Palate Operations. Plast. Reconstr. Surg. 39: 2; 168, Feb. 1967.

Webster, G.V.: Random Reflections on Rhinoplasty. Plast. Reconstr. Surg. 39: 2; 147, Feb. 1967.

\section{Head and Neck Surgery}

Batsakis, J.G., et al.: Synovial Sarcomas of the Neck. Arch. Otolaryng. 85: 3; 327, Mar. 1967.

Harrison, D.F.N.: The Use of Hypothermia in Intra-Arterial Chemotherapy for Head and Neck Cancer. J. Laryng. (Lond.) 81: 2; 173, Feb. 1967.

Mesara, B.W., et al.: Hibernoma of the Neck. Arch. Otolaryng. (Chicago) 85: 2; 199, Feb. 1967.

Millard, Jr. D.R., et al.: Immediate Repair of Radical Resection of the Anterior Arch of the Lower Jaw. Plast. Reconstr. Srug. 39: 2; 153, Feb. 1967.

Leden, H.v., et al.: Cryosurgery of the Head and Neck. Arch. Otolaryng. 85: 1; 93, Jan. 1967.

Roseman, D.M.: Carotidynia. Arch. Otolaryng. 85: 1; 81, Jan. 1967.

Sabri, J.A., et al.: Malignant Mixed Tumor of the Vocal Cord. Arch. Otolaryng. 85: 3; 332, Mar. 1967.

Wuketich, St., et al.: Lymphadenoma sebaceum der Parotis. Archiv klin. exper. Ohren-,Nasenund Kehlkopfheilk. 187: 3; 836, 1966.

\section{Broncho-esophagology}

Alavi, K.: Watermelon Seed in the Tracheobronchial Tree in Iran. Arch. Otolaryng. (Chicago) 85: 2; 214, Feb. 1967.

Blancato, L.S., et al.: Intravenous Lidocaine with General Anesthesia for Endoscopy. Arch. Otolaryng. (Chicago) 85: 2; 207, Feb. 1967.

Ganz, H.: Enzymmuster von Tumoren der oberen Luft- und Speiswege. Archiv klin. exper. Ohren-, Nasen- und Kehlkophfeilk. 187: 3; 785, 1966.

Koop, S.H., et al.: The Safety of Mediastionscopy. Arch. Otolaryng. (Chicago) 85: 1; 47, Jan. 1967.

Schratter, H.: Röntgenbefunde zur Differentialdiagnose bronchialer Erkrankungen. Mschr. Ohr. hk., Wit n 101: 1; 39, 1967.

12. Miscellanekus

Andersnn, J.E.: Progress Report: Progress in Allergy: 1965. Arch. Otolaryng. (Chicago) 85: 3; 342, Mar. 1967.

Boenninghaus, H.-G.: Prof. Dr. Richard Mittermaier zum 70. Geburtstag. Z. Laryng. Rhinol. 46: 1; 1, Jan. 1967,

Chasin, W.D., et al.: Hydrogen Peroxide and Irradiation of Tumors. Arch. Otolaryng. (Chicago) 85: 2; 151, Feb. 1967.

Connell, J.T.: Long-Acting Antihistamine-Decongestant Evaluation. Arch. Otolarng. (Chichago) 85: 2; 218, Feb. 1967.

Folin. J., et al.: Posture and Anaesthesia during Oesophago-Gastroscopy. Acta otolaryng. (Stockh.) 63: 1; 17, Jan. 1967

Fowler, E.P., Historical Vignette: Harvey Fletcher, Arch. Otolaryng. 85: 1; 107, Jan. 1967.

Rasmussen, P.E.: Middle ear and Maxillary Sines during Nitrous Oxide Anesthesia. Acta otolaryng. (Stockh.) 63: 1; 7, Jan. 1967.

Saunders, W.H.: Oxytetracycline-Treated Packing. Arch. Otolaryng. 85: 1; 105, Jan. 1967.

Shambaugh, Jr., G.E.: Dr. John Lindsay Retires, but Remains Active. Arch. Otolaryng. 85: 3; 237, Mar. 1967.

Tos, M., et al.: Laryngeal Complications of Percutaneous Cerebral Angiography. Acta otlaryng. (Stockh.) 63: 1; 23, Jan. 1967.

Sir Victor, Negus : J. Laryng. (Lond.) 81 ; 3; 259; Mar. 1967. 